
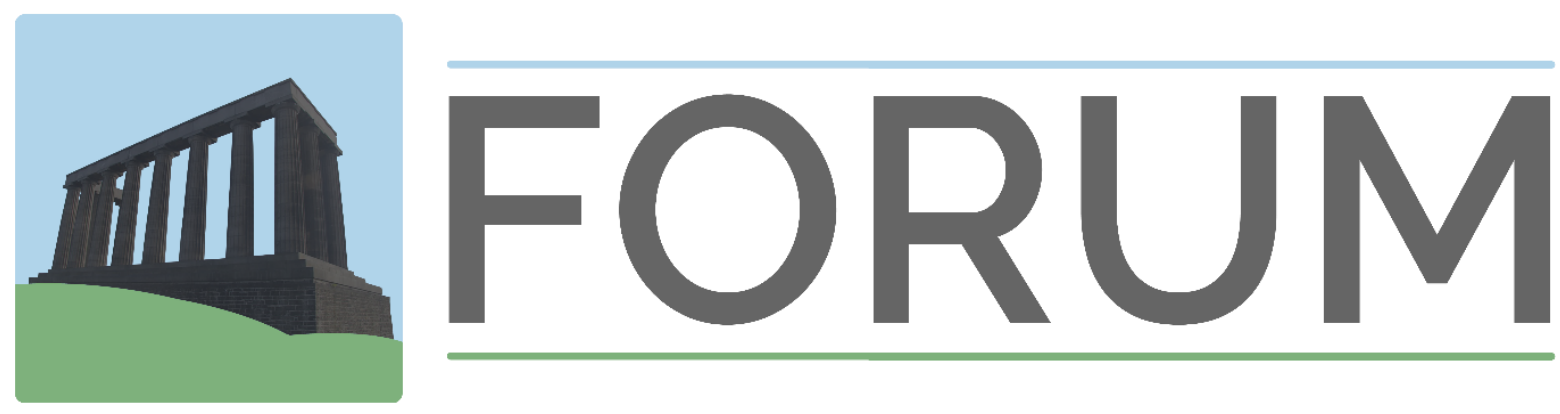

University of Edinburgh

Postgraduate Journal of Culture and the Arts

Issue 32 | Autumn 2021

Title

Author

Publication

Issue Number

Issue Date

Publication Date

Editor
Building Back, Building from Scratch

Marco Ruggieri

FORUM: University of Edinburgh Postgraduate Journal of Culture \& the Arts 32

Autumn 2021

$01^{\text {st }}$ October 2021

Marco Ruggieri and Amy Waterson

FORUM claims non-exclusive rights to reproduce this article electronically (in full or in part) and to publish this work in any such media current or later developed. The author retains all rights, including the right to be identified as the author wherever and whenever this article is published, and the right to use all or part of the article and abstracts, with or without revision or modification in compilations or other publications. Any latter publication shall recognise FORUM as the original publisher. 


\title{
Building Back, Building from Scratch
}

\author{
Marco Ruggieri \\ University of Edinburgh
}

The $32^{\text {nd }}$ edition of FORUM explores the theme of the aftermath as represented in literature and visual arts. We have brought together a collection of eight articles that examine, each in its own peculiar way, cases in which artists and writers have depicted the consequences of an event, situation, or ideological shift which changed the course of life for an individual or entire communities. The cover picture for 'The Aftermath', John Florea's A Poker-Face German Girl, taken in 1945 in the city of Cologne destroyed by the bombings, fully represents this condition and holds together the individual and the collective dimension of tragedies and their aftermath.

Our society is currently confronted not only with the ongoing challenge of a worldwide health emergency but also with that of "building back better". But what is the real meaning of this widespread motto? The essays in this issue investigate what "change" really means or implies, and what remains in the aftermath of what happened before. Building a fairer and safer future is not the only challenge that post-pandemic societies will face. They will also have to cope with a double trauma: on the one hand, the losses and the suffering; on the other hand, the trauma of having realised overnight the inherent fragility of human life and of a world that, from the second post-war period onwards, we had considered infrangible and unstoppable.

In many parts of the world, the Second World War acted as an unprecedented cultural watershed. For this reason, all the representations of the "new world" after the war had to deal with the re-emergence of the past and its traumatic memories (Judt). It is the case, for instance, with the post-war cinema of the French New Wave (Neupert) and the Italian Neorealism (Leavitt), whose very names testify to their intention of overcoming the cinematography of the past and describing the new world with a new cinematic language.

In the context of the aftermath of the Second World War, the representation of the difficult coexistence with the memories of the Holocaust is particularly meaningful. In his volume on the aftermath of the Holocaust, Michael Rothberg identified in Art Spiegelman's graphic novel Maus (2003) a significant example of "how we approach the events of the genocide and how we represent them to ourselves and to others" (Rothberg 2). Spiegelman 
tells in the unusual form of the comics about the conversations he had with his father about his experience in the Nazi extermination camps. The narration of this tragic experience is a story within the story of the author and his life in New York between the 1970s and the 1980s, suddenly forced to confront the collective repressed memories of the Holocaust. As Rothberg writes, Maus shows that "some confrontation with the reality of the events is unavoidable no matter how far removed one might seem to be from the past" (7).

In this light, the contributions included in our $32^{\text {nd }}$ issue explore representations of communities and individuals that had to build back - or build from scratch - while carrying the burden of a heavy legacy. They address both the major historical implications as well as the intimacies of characters within their fictional worlds, illustrating how literature and the arts have handled aftermaths which are global and personal in impact. 


\section{Works Cited}

Florea, John. A Poker-Face German Girl, 1945, http://www.stevenkasher.com/artists/johnflorea. Accessed 10 September 2021.

Judt, Tony. Postwar: A History of Europe since 1945. Penguin Press, 2005.

Leavitt IV, Charles L. Italian Neorealism: A Cultural History. University of Toronto Press, 2020.

Neupert, Richard John. A History of the French New Wave Cinema. University of Wisconsin Press, 2007.

Rothberg, Michael. Traumatic realism the demands of Holocaust representation. University of Minnesota Press, 2000.

Spiegelman, Art. The Complete MAUS. Penguin Books, 2003. 


\section{Author Biography}

Marco Ruggieri is a final year PhD student at The University of Edinburgh and the Edinburgh reporter for the Italian newspaper Il Manifesto. His doctoral research (John Orr Award) studies Umberto Eco's theory of mass culture and narrative works, investigating their semiotic foundations and their historical and sociocultural background. He has been the Co-Editor of FORUM since March 2021. 